\title{
Grazing Intensity Guidelines
}

\author{
JERRY L. HOLECHEK AND DEE GALT
}

$\mathrm{G}$ razing management on rangelands is based on controlling the intensity, timing, frequency, and selectivity of grazing animals. Grazing intensity has been considered to be the most critical of these factors because high intensity grazing damages the eaten plants. Considerable controversy has existed over how grazing intensity should be measured. Over the past 7 years as researchers and consultants we have had the opportunity to evaluate grazing intensity on several rangeland sites in New Mexico using a variety of techniques. As a result of this experience we have been able to test and improve the approach of Anderson and Currier for evaluating grazing intensity that has reasonable simplicity, rapidity, repeatability, and accuracy. We will describe our use of the approach and discuss modifications we have developed for some major rangeland types in New Mexico.

\section{The Problem}

A number of reviews have pointed out the problems associated with the various methods for evaluating grazing intensity. The most commonly used approach in various stocking rate studies has been using percent of forage utilized. It is generally more understandable to ranchers and the public than qualitative assessments of grazing intensity such as light, moderate, or heavy, or quantitative measurements such as residual vegetation, stubble heights, or percentages of ungrazed plants. Over long time periods percent forage use has been well associated with vegetational composition shifts, changes in forage production, livestock productivity, and financial returns. It has commonly been used as a basis for the harvest coefficient when stocking rates are determined. The harvest coefficient is the percentage of annual forage production assigned to livestock consumption.

In spite of these advantages, percent use has several drawbacks as a sole measure of grazing intensity. It is not easy to measure and, therefore, accuracy and precision can be important problems. Most importantly, during individual years determining percent use is difficult and does not always reflect grazing severity. Utilization percentages that are light in wet years due to regrowth can adversely impact rangeland health in dry years.

Various qualitative grazing intensity procedures involve visual inspection of range for characteristics such as vegetation patchiness, remaining seed stalks, hedging of browse plants, presence of livestock trails, proportion of ungrazed plants, soil cover, and so on. Based on these characteristics, grazing intensity for a particular range can be characterized as light to unused, conservatively used, moderately used, heavily used, or severely used. If observers are properly trained with pictures and inspeciions of pastures with known grazing intensities, thoroughly cover a range unit, and do some quantitative cross checking with stubble heights or residues, we have found qualitative assessments of grazing intensity can be fairly reliable.

Measurement of residual vegetation can be time consuming. Specific levels needed for protection in many range types have not been determined. Exceptions are the California annual grassland type and the shortgrass prairie in Colorado. We believe enough information is now available that residue guidelines could be developed for most range sites in the United States.

Residual vegetation better reflects grazing severity than percent use data because it determines how well wildlife, watershed, livestock, and esthetic values are maintained.

In recent years grass stubble height measurements have received greater use in grazing intensity surveys because they are closely associated with residual vegetation. Minimum stubble height guidelines have been developed for various range grasses (see Heady and Child 1994, Holechek et al. 1998). Generally, we have found stubble heights can be evaluated quickly, accurately, and with reasonable repeatability among observers.

\section{Our Approach}

Basically our approach to evaluating grazing follows Anderson and Currier with some modifications. We use general pasture reconnaissance, grazing intensity categories, mapping of use zones, and stubble heights as indicators of grazing severity. We have modified the grazing intensity categories based on research from New Mexico rangelands (Table 1). In addition, we establish 1-2 key areas per pasture for more intensive monitoring. Typically we select key areas that are representative of the pasture and 0.75 to 1.00 mile from water. Here we evaluate end of grazing season ungrazed forage production using 3 to 5 large (16 sq. feet) moveable cages; grazed forage residues at the end of the grazing period; and grazed and ungrazed stubble heights of key grasses. Prior to forage regrowth after dormancy we also take photographs along permanent transects as suggested by Sharp et al. (Figures 1, 2, and 3). We always calculate a percent use coefficient based on forage standing crop inside and outside the cages. We recognize that cages can differentially affect forage production compared to uncaged areas, therefore we also attempt to cross check this coefficient by clipping some ungrazed or lightly grazed patches of vegetation on the site and comparing that with grazed areas. While we consider the percent use coefficient useful as an indicator of harvest efficiency and grazing severity, we do not believe it should be used as a sole measure 
Table 1. Qualitative characteristics of grazing intensity categories used to characterize New Mexico rangelands.

\begin{tabular}{lcc}
\hline \hline $\begin{array}{l}\text { Qualitative Grazing } \\
\text { Intensity Category }\end{array}$ & $\begin{array}{c}\text { Use of Forage } \\
\text { by Weight }\end{array}$ & $\begin{array}{c}\text { Qualitative Indicators } \\
\text { of Grazing Intensity }\end{array}$ \\
\hline Light to non-use & $-(\%)-.-$ & $\begin{array}{l}\text { Only choice plants and areas show } \\
\text { use; There is no use of poor forage }\end{array}$
\end{tabular}

Conservative $\quad 31-40$
plants.

Conservative

$31-40$

Moderate

$41-50$

Heavy

$51-60$

Severe

$61+$

of grazing intensity due to precision and accuracy limitations. On the basis of this information we have been able to develop stubble height/utilization guides for shortgrass-pinyon/juniper, Chihuahuan Desert, and mountain grassland range types that should be of practical value to range managers and ranchers. We suggest that they are guides and may not apply in all situations. However, managers should be able to develop their own guides using our approach.

\section{Guidelines for Shortgrass-Pinyon/Juniper}

We developed our guide (Table 2) for this range type from surveys we conducted on 3 different ranches ( 2 in western New Mexico, 1 in central New Mexico). We found that residue guides developed by Bement for blue grama rangelands in Colorado corresponded well with forage use levels, stubble heights, and our qualitative assessments of pasture grazing intensity in New Mexico. We have found a close correlation between blue grama stubble heights and forage residue levels. The minimum stubble height of 1.5 to 2 inches for blue grama recommended by Crafts and Glendening corresponded well to moderate grazing (41-50\% use of forage) on several pastures we evaluated.

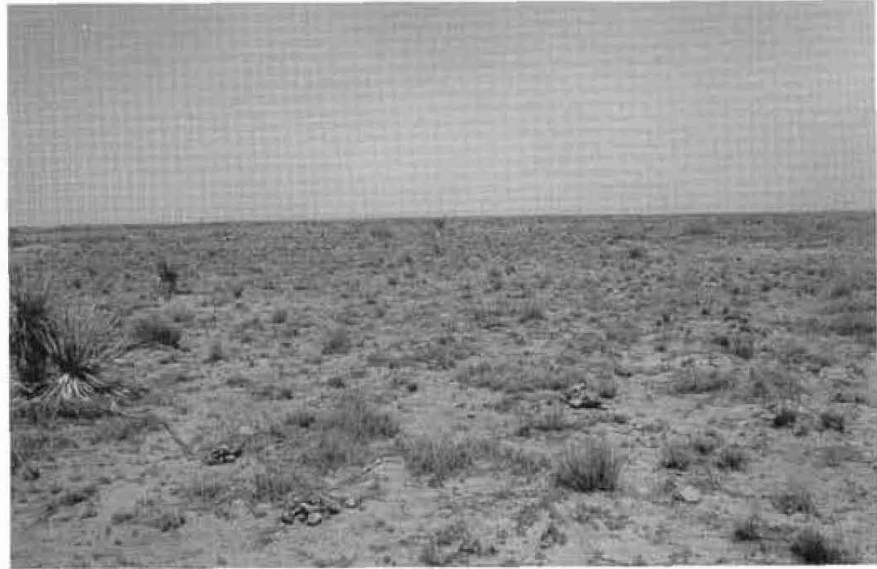

Fig. 1. Moderately grazed rangeland dominated by black grama on the Chihuahuan Desert Rangeland Research Center in southcentral New Mexico in late May, 1999.



Fig. 2. Conservatively grazed rangeland dominated by black grama on the Chihuahuan Desert Rangeland Research Center in late May, 1999.



Fig. 3. Ungrazed (left) and severely grazed (right) Chihuahuan Desert grassland ranges in southcentral New Mexico in early June, 1999. 
Table 2. Grazing intensity guide for shortgrass-pinyon/juniper rangelands in New Mexico.

\begin{tabular}{lcccc}
\hline \hline $\begin{array}{c}\text { Qualitative } \\
\text { Grazing Intensity } \\
\text { Category }\end{array}$ & $\begin{array}{c}\text { Use } \\
\text { of Forage } \\
\text { by Weight }\end{array}$ & \multicolumn{2}{c}{$\begin{array}{c}\text { Stubble } \\
\text { Height } \\
\text { Guide }\end{array}$} & $\begin{array}{c}\text { Forage } \\
\text { Residue } \\
\text { Guide }\end{array}$ \\
& & $\begin{array}{c}\text { Blue } \\
\text { Grama }\end{array}$ & $\begin{array}{c}\text { Western } \\
\text { Wheatgrass }\end{array}$ \\
\hline Light to non-use & $--(\%)--$ & $-\cdots--$ (inches)---- & (Ibs/acre) \\
Conservative & $31-40$ & $2.5+$ & $7.0+$ & $435+$ \\
Moderate & $41-50$ & $2.0-2.5$ & $4.0-5.0$ & $350-435$ \\
Heavy & $51-60$ & $1.5-2.0$ & $3.0-4.0$ & $265-350$ \\
Severe & $>60$ & $1.0-1.5$ & $2.0-3.0$ & $180-265$ \\
\hline
\end{tabular}

We have found residue guidelines developed by Bement (1969) for blue grama rangelands in Colorado apply well to New Mexico blue grama rangelands.

\section{Guidelines for Chihuahuan Desert}

Our guide (Table 3 ) for this range type was developed primarily from experimental pastures on the Chihuahuan Desert Rangeland Research Center in southcentral New Mexico and a large ranch in southeastern Arizona. Stubble heights of black grama generally associated well with measured forage use levels. Black grama productivity is impaired when it is grazed below a 3 inch stubble height. Cattle on the Chihuahuan Desert Rangeland Research Center experienced weight losses when black grama stubble height fell below 3 inches.

\section{Guidelines for Mountain Grassland}

Our stubble height guide (Table 4) for mountain grassland ranges was developed from ranch surveys we conducted in westcentral, southcentral, and northcentral New Mexico. Johnson found stubble height of Arizona fescue was well related to forage use and vigor on mountain grassland in Colorado. Our surveys were in agreement with Johnson that a 6 inch stubble height on Arizona fescue corresponds to moderate use.

\section{Guidelines for Shrubs}

Shrubs such as common winterfat, fourwing saltbush, and mountain mahogany were important forage components on several of the rangelands we evaluated. Based on relationships between percent use of browse and percentages of leaders grazed, we have developed a grazing intensity guide (Table 5) that can be applied to most shrubs. Generally, moderate browsing on shrubs involves visible use on $51-80 \%$ of the leaders or $51-75 \%$ use of current year's growth by weight (Fig. 4).

\section{Some Final Thoughts}

The key feature of our procedure is that it uses a combination of indicators to assess grazing intensity. We have found that ranchers, other range managers, and students trained with

Table 3. Grazing intensity guide for Chihuahuan Desert rangelands in New Mexico.

\begin{tabular}{|c|c|c|c|c|c|c|c|}
\hline \multirow[t]{2}{*}{$\begin{array}{c}\text { Qualitative } \\
\text { Grazing Intensity } \\
\text { Category }\end{array}$} & \multirow[t]{2}{*}{$\begin{array}{c}\text { Use of } \\
\text { Forage } \\
\text { by Weight }\end{array}$} & \multicolumn{6}{|c|}{$\begin{array}{l}\text { Stubble } \\
\text { Height } \\
\text { Guide }\end{array}$} \\
\hline & & $\begin{array}{l}\text { Black } \\
\text { Grama }\end{array}$ & Dropseed & Threeawn & Tobosa & Sacaton & $\begin{array}{c}\text { Sideoats } \\
\text { Grama }\end{array}$ \\
\hline & $---(\%)---$ & & 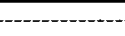 & --- (inc & ------- & +----- & 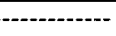 \\
\hline Light to non-use & $0-30$ & $5+$ & $9+$ & $5+$ & $9+$ & $16+$ & $9+$ \\
\hline Conservative & $31-40$ & $4-5$ & $8-9$ & $4-5$ & $7-9$ & $14-16$ & $8-9$ \\
\hline Moderate & $41-50$ & $3-4$ & $6-8$ & $3-4$ & $5-7$ & $12-14$ & $6-8$ \\
\hline Heavy & $51-60$ & $2-3$ & $4-6$ & $2-3$ & $3-5$ & $10-12$ & $4-6$ \\
\hline Severe & $>60$ & $<2$ & $<4$ & $<2$ & $<3$ & $<10$ & $<4$ \\
\hline
\end{tabular}

Table 4. Grazing intensity guide for mountain grassland rangeland in New Mexico.

\begin{tabular}{|c|c|c|c|c|c|c|}
\hline \multirow[t]{3}{*}{$\begin{array}{l}\text { Qualitative } \\
\text { Grazing Intensity } \\
\text { Category }\end{array}$} & \multirow[t]{3}{*}{$\begin{array}{c}\text { Use of } \\
\text { Forage } \\
\text { by Weight }\end{array}$} & \multicolumn{5}{|c|}{$\begin{array}{c}\text { Stubble } \\
\text { Height } \\
\text { Guide }\end{array}$} \\
\hline & & $\overline{\text { Arizona }}$ & Western & Intermediate & Mutton grass & Mountain \\
\hline & & Fescue & Wheatgrass & Wheatgrass & $\begin{array}{c}\text { \& Kentucky } \\
\text { Bluegrass }\end{array}$ & Muhly \\
\hline Light to non-use & $\begin{array}{c}--(\%)-- \\
0-30\end{array}$ & $8+$ & $7+$ & $\begin{array}{c}-(\text { (inches) } \\
10+\end{array}$ & - & $5+$ \\
\hline Conservative & $31-40$ & $6-7$ & $4-5$ & $8-10$ & $4-5$ & $4-5$ \\
\hline Moderate & $41-50$ & $5-6$ & $3-4$ & $6-8$ & $3-4$ & $3-4$ \\
\hline Heavy & $51-60$ & $4-5$ & $2-3$ & $4-6$ & $2-3$ & $2-3$ \\
\hline Severe & $>60$ & $<4$ & $<2$ & $<4$ & $<2$ & $<2$ \\
\hline
\end{tabular}


Table 5. Grazing intensity guide for key shrub species (common winterfat, fourwing saltbush, mountain mahogany) on New Mexico rangelands.

\begin{tabular}{lcc}
\hline \hline $\begin{array}{c}\text { Qualitative } \\
\text { Grazing Intensity } \\
\text { Category }\end{array}$ & $\begin{array}{c}\text { Use of Current } \\
\text { Year Browse } \\
\text { Production by Weight }\end{array}$ & $\begin{array}{c}\text { Leaders } \\
\text { Browsed }\end{array}$ \\
\hline Light to non-use & $-(\%)-$ & $-(\%)-$ \\
Conservative & $<30$ & $<15$ \\
Moderate & $31-50$ & $16-50$ \\
Heavy & $51-75$ & $51-80$ \\
Severe & $75-90$ & $81-100$ \\
& $>90$ & All leaders plus old \\
growth used
\end{tabular}

our procedure were remarkably consistent and accurate in categorizing grazing intensity as light, conservative, moderate, heavy, or severe. Generally, observers have shown high repeatability when stubble heights and residues were used as quantitative checks on qualitative estimates. After 4-8 hours of training, we have successfully used teams of 3 trained observers to evaluate grazing intensity on land units as large as 10,000 acres in a day. Here we use the average estimates of the 3 observers as our final utilization figure for each pasture.

We consider annual assessment of grazing intensity to be essential for effective management of any range unit. It is the basis for annual stocking rate adjustments and application of various tools to improve livestock distribution. However, we emphasize grazing intensity is as much a qualitative as a quantitative characteristic. Managers must recognize that attainment of specific use levels is nearly impossible on a year over year basis due to the vagaries of climate. Instead, we believe they should be a target across $5-10$ year time periods. On publicly owned rangelands dominated by native vegetation, we believe managers should avoid the heavy grazing category (exceeding $50 \%$ use) when various zones and key areas within a range unit are averaged within any year. There should be some tolerance for heavy grazing on a portion of a pasture (up to $30 \%$ ). It is our strong opinion that immediate managerial changes (reduction in numbers) are needed any time grazing falls into the severe category on one third or more of a range

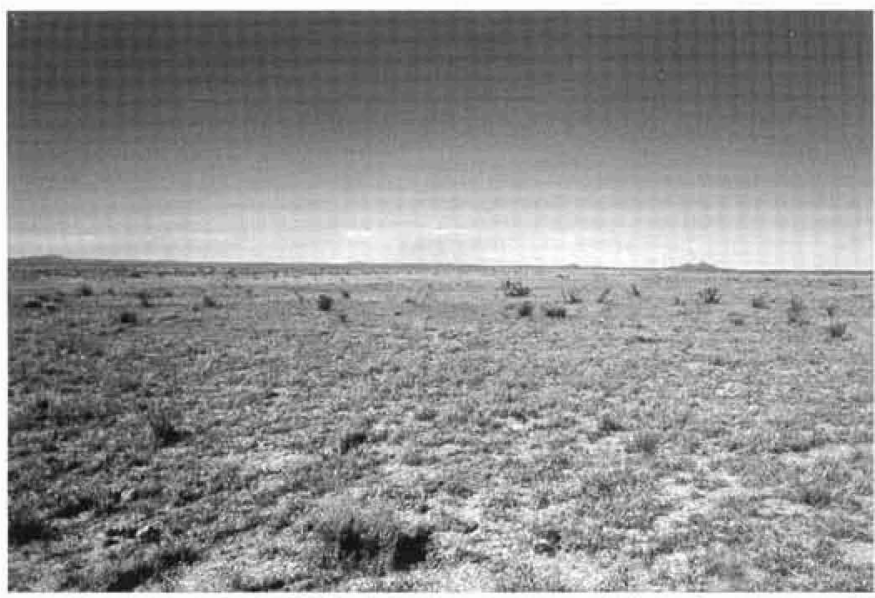

Fig. 4. Moderately used fourwing saltbush-blue grama rangeland in westcentral New Mexico in June 1999. Most leaders of the fourwing saltbush plants show some browsing and range has patchy appearance. unit. Ranchers should be encouraged to avoid heavy use year after year on the same key areas. This is where rotation grazing systems, regulation of access to watering points, strategic fencing, herding, and placement of salt can be useful.

\section{Further Reading}

Anderson, E. W. and W. F. Currier. 1973. Evaluating zones of utilization. J. Range Manage. 26:87-91.

Bement, R. E. 1969. A stocking rate guide for blue grama range. J. Range Manage. 22:83-86.

Cook, C. W. and R. D. Child. 1971. Recovery of desert plants in various states of vigor. J. Range Manage. 22:339-343.

Crafts, E. C. and G. E. Glendening. 1942. How to graze blue grama on southwestern ranges. U.S .Dept. Agr. Leaflet 215:1-8.

Frost, W. E., E. L. Smith, and P. R. Ogden. 1994. Utilization guidelines. Rangelands 16:256-259.

Garrison, G. A. 1953. Effects of clipping on some range shrubs. J. Range Manage. 6:309-317.

Heady, H. F. and R. D. Child. 1994. Rangeland ecology and management. Westview Press, San Francisco, Calif.

Hooper, J. F. and H. F. Heady. 1970. An economic analysis of optimum rates of grazing in the California annual type. J. Range Manage. 23:307-311.

Holechek, J. L. 1996. Financial returns and range condition on southern New Mexico ranches. Rangelands 16:237-240.

Holechek, J. L., R. D. Pieper, and C. H. Herbel. 1998. Range management: principles \& practices. 3rd Edition. Prentice Hall, Upper Saddle River, N.J.

Hutchings, S. S. and G. Stewart. 1953. Increasing forage yields and sheep production of intermountain winter ranges. U.S. Dept. Agr. Circ. 925.

Jasmer, G. E. and J. L. Holechek. 1984. Determining grazing intensity on rangeland. J. Soil \& Water Conserv. 39:32-35.

Johnson, W. M. 1953. Effect of grazing intensity upon vegetation and cattle gains on ponderosa pine-benchgrass ranges of the front range of Colorado. U.S. Dept. Agr. Circ. 929.

Paulsen, H. A., Jr. and F. N. Ares. 1962. Grazing values and management of black grama and tobosa grasslands and associated shrub ranges of the southwest. U.S. Dept. Agr. Tech. Bull. 1270.

Schmutz, E. M. 1983. Browsed-class method of estimating shrub utilization. J. Range Manage. 36:632-637.

Sharp, L., K. Sanders, and N. Rimbey. 1994. Management decisions based on utilization-Is it really management? Rangelands 16:38-40.

Valentine, K. A. 1970, Influence of grazing intensity on improvement of deteriorated black grama range. New Mexico Agr. Expt. Sta. Bull. 553.

Valentine, J. F. 1990. Grazing management. Academic Press, New York.

Willard, E. E. and C. M. McKell. 1973. Simulated grazing management systems in relation to shrub growth responses. J. Range Manage. 26:171-174.

Winder, J. A., C. C. Bailey, M. G. Thomas, and J. L. Holechek. 2000. Breed and stocking rate effects Chihuahuan Desert Cattle production. J. Range Manage. 53:32-39.

The authors are professor of Range Science, Department of Animal and Range Sciences, New Mexico State University, Las Cruces, New Mexico 88003 and private range consultant, Las Cruces, New Mexico 88003. This paper was supported by the New Mexico Agricultural Experiment Station and was part of project 1-5-27417. 